\title{
ARTIGO - PRÁTICAS DE LEITURA, GÊNEROS E SUPORTES TEXTUAIS DO CONTEXTO FAMILIAR NA PERSPECTIVA DE CRIANÇAS EM CLASSE DE ALFABETIZAÇÃO
}

\author{
LUCIANA PICCOLI' \\ ORCID: https://orcid.org/0000-0001-6213-175X \\ MARIA ISABEL HABCKOST DALLA ZEN' \\ ORCID: https://orcid.org/0000-0002-0774-7129
}

I Universidade Federal do Rio Grande do Sul, Faculdade de Educação, Porto Alegre, RS, Brasil.

Luciana Piccoli - Doutora em Educação pela Universidade Federal do Rio Grande do Sul (UFRGS). Professora Associada do Departamento de Ensino e Currículo da Faculdade de Educação (FACED) da UFRGS - Porto Alegre/RS, Brasil. Coordenadora do Grupo Aula: Alfabetização, Linguagem e Ensino.

E-mail: < luciana.piccoli@ufrgs.br >.

Maria Isabel H. Dalla Zen - Doutora em Educação pela Universidade Federal do Rio Grande do Sul (UFRGS). Professora Associada aposentada do Departamento de Ensino e Currículo da Faculdade de Educação (FACED) da UFRGS - Porto Alegre/RS, Brasil. Integrante do Núcleo de Estudos sobre Currículo, Cultura e Sociedade (NECCSO). E-mail:< beladzen@terra.com.br >.

RESUMO: Neste artigo analisam-se práticas de leitura vinculadas ao contexto familiar de crianças de segundo ano do Ensino Fundamental de escola municipal de Porto Alegre/RS, bem como textos e materiais utilizados por elas em tais práticas. Situa-se nos campos do letramento, alfabetização e leitura, vistos sob os enfoques social, cultural, linguístico e pedagógico. Para geração dos dados, foram realizadas discussões com crianças em grupos focais, sendo os encontros registrados em diário de campo. A partir da análise dos dados, buscou-se identificar as práticas de leitura mais recorrentes apresentadas nos eixos: variedade de materiais e práticas de leitura apontada pelos participantes, protagonismo da criança-leitora em seu contexto familiar, perspectiva das crianças sobre gêneros e suportes de leitura. Constatouse que as crianças fizeram mais referência ao suporte do que ao gênero, sendo tal resultado significativo para o planejamento de práticas escolares de alfabetização e leitura, as quais são inventariadas ao final do texto.

Palavras-chave: Práticas de leitura. Gêneros textuais. Suportes textuais. Alfabetização.

READING PRACTICES, GENRES AND SUPPORTING READING MATERIAL IN THE FAMILY ENVIRONMENT THROUGH THE CHILDREN'S PERSPECTIVE IN A LITERACY CLASS

ABSTRACT: This article analyzes reading practices in the family environment of children in a second-grade class at a municipal elementary school in Porto Alegre/RS, as well as the texts and material used by the children. This study 
is situated in the fields of literacy and reading, under social, cultural, linguistic and pedagogical approaches. For data production, discussions involved children in focal groups, and all meetings were recorded in the field journal. The analysis of the data identified the most recurrent reading practices present in the axes: variety of reading material and reading practices indicated by the children, role of the child-reader within the family environment, children's perspective regarding genres and reading material. It was established that the children referred more to the reading material than to the genre, and this result is of higher significance in the planning of classroom literacy and reading practices, which are assessed by the end of the text.

Keywords: Reading practices. Textual genres. Reading material. Literacy.

\section{PREÂMBULO}

A pouca familiaridade das crianças das camadas populares com leitura e escrita é comumente atribuída à ausência de livros e material escrito, em geral, no contexto familiar, social e cultural dos alunos. Essa recorrente preocupação de professores, predominantemente de escolas públicas, constatada por Magda Soares (2010), não leva em conta o que ela apontou ao discutir as implicações das práticas de letramento para pesquisas: a necessidade de conhecer os usos da leitura e da escrita nesses contextos e suas diferenças em relação aos usos escolares. Nessa ocasião, a pesquisadora sublinhou a escassez de estudos brasileiros direcionados a identificar e compreender as práticas de leitura e de escrita desenvolvidas na escola e suas relações com as práticas sociais para além dessa instituição. Cerca de uma década após essa constatação de Soares, uma recente busca em plataformas de repositórios digitais evidencia a profusão de estudos sobre práticas de letramento de crianças de camadas populares e suas famílias por meio de abordagens descritivas e explicativas, porém deixando ainda as relações com as práticas escolares em segundo plano. Este estudo, então, intenta diferenciar-se dessa maioria pela posição não só investigativa, mas também pedagógica que o caracteriza.

Provocada por essa lacuna inicial apontada por Soares, a presente pesquisa abordou práticas de leitura de crianças em fase de alfabetização ocorridas fora do ambiente escolar. O objetivo deste trabalho é, portanto, visibilizar e analisar práticas de leitura vinculadas ao contexto familiar de crianças de uma turma de segundo ano do Ensino Fundamental de uma escola municipal de Porto Alegre/RS, bem como textos e materiais utilizados por elas em tais práticas. Os dados e as análises aqui apresentados são oriundos de projeto de pesquisa ${ }^{1}$ que se situa no campo dos estudos do letramento e da alfabetização e se 
relaciona às práticas de leitura e escrita de uma comunidade popular atendida pela escola referida, localizada em uma periferia urbana.

Este estudo é um recorte do material empírico produzido durante a pesquisa. A etapa sobre a qual nos debruçamos neste texto consistiu em encontros com doze crianças participantes, que à época tinham entre sete e oito anos de idade. Nesses encontros, elas apresentavam materiais de leitura trazidos de casa, os quais, segundo elas, eram utilizados fora da escola. Entretanto, os materiais, por si só, "não nos contam" sobre seus modos, tempos e espaços de uso. Assim, como esperado em uma pesquisa cuja metodologia é grupo focal, ampliamos as lentes para acessar as práticas, os usos e os significados da leitura na vida cotidiana das crianças e de suas famílias, o que se constituiu como nosso objeto de investigação.

Como uma das intenções deste trabalho é estabelecer relações dos resultados com o planejamento de práticas escolares de alfabetização e leitura, nos cabe aqui, além de um olhar pesquisador, levando em conta as especificidades conceituais envolvidas, um olhar pedagógico. Essa posição está amparada no alerta para contextos de ensino também feito por Soares (2016) sobre a aprendizagem inicial da língua escrita, que deve buscar o desenvolvimento harmônico do todo já que, argumenta ela, essa é a natureza dos atos de ler e de escrever, na qual a complexa interação entre as práticas sociais da língua escrita e quem lê ou escreve exige o exercício simultâneo de variadas competências. Este é, portanto, o convite que se faz aqui: uma aposta em direção à possibilidade e à potencialidade de conciliação, em pesquisa, das relações entre as práticas de leitura que ocorrem fora da escola com as que têm lugar didático dentro dela.

\section{ANCORAGEM TEÓRICO-METODOLÓGICA}

O conceito de alfabetização passou (e continua passando) por diversas interpretações no que se refere a possíveis compreensões: da alfabetização que focaliza a aprendizagem inicial do sistema de escrita à alfabetização que permite ler com autonomia diferentes gêneros textuais e escrever atendendo a diferentes finalidades sociodiscursivas. É consenso, para pesquisadores da área (MORAIS, 2012; SOARES, 2016), que o primeiro nível, por si só, é insuficiente para as demandas das sociedades em que vivemos, e que o segundo apenas se concretiza na dependência do primeiro. Magda Soares, pesquisadora referência no Brasil sobre o tema, em recente publicação, defende que são três as principais facetas de inserção dos sujeitos no mundo da escrita: 
[...] a faceta propriamente linguística da língua escrita - a representação visual da cadeia sonora da fala [...]; a faceta interativa da língua escrita - a língua escrita como veículo de interação entre as pessoas, de expressão e compreensão de mensagens; a faceta sociocultural da língua escrita - os usos, funções e valores atribuídos à escrita em contextos socioculturais [...] (SOARES, 2016, p. 28-29) [grifos do original]

Enquanto a autora designa a primeira faceta como alfabetização, as duas últimas são consideradas como letramento. Ainda explica que dessas três facetas decorrem objetos de conhecimento distintos na composição do processo de aprendizagem inicial da língua escrita, sendo a faceta linguística alicerce das outras duas.

Neste texto, então, ainda que as facetas sociocultural e interativa sejam privilegiadas, à faceta linguística será conferido um lugar de destaque. Nossa argumentação se desenvolve pela necessidade de considerar as práticas de leitura das crianças também a partir dos elementos linguísticos que as subjazem, já que, se apropriando do sistema alfabético-ortográfico e das convenções da escrita, tais aspectos se tornam relevantes do ponto de vista investigativo e pedagógico.

Ao invés de investirmos em uma diferenciação entre os conceitos de alfabetização e letramento - o que já foi exaustivamente feito na literatura brasileira -, nossa opção aqui é assinalar as principais competências que uma criança precisa consolidar para ser considerada alfabetizada e, segundo Soares (2016, p. 346), também letrada, sendo, portanto, “[...] aquela que não só sabe ler e escrever, mas também domina habilidades básicas de leitura e escrita necessárias para a participação em eventos de letramento tão frequentes nas sociedades contemporâneas". Considerando essas perspectivas, buscamos relacionar, às práticas, quais habilidades estão em curso e quais poderiam ser pedagogicamente desenvolvidas. Desse modo, situamos este trabalho nos campos do letramento, da alfabetização e da leitura, vistos sob diferentes enfoques: social, cultural, linguístico e pedagógico. A complexidade dos dados nos exigiu essas lentes multifacetadas para analisar as perspectivas das crianças sobre a leitura, além de pensar pedagogicamente o desenvolvimento das habilidades nelas implicadas.

No que se refere à abordagem metodológica, nos amparamos em Graue e Walsh (2003) ao alertarem que sabemos muito mais sobre o que se passa com as crianças na escola do que em outro lugar fora desse contexto, sendo esse mais um motivo que mobilizou a busca por informações, advindas das práticas de leitura, fora da instituição escolar. Para gerar os dados de "outro lugar", ou seja, de fora da sala de aula, planejamos discussões envolvendo doze crianças que compuseram três grupos focais. Gatti (2005, p. 11) esclarece que o trabalho com essa abordagem permite "[...] compreender 
processos de construção da realidade por determinados grupos sociais, compreender práticas cotidianas, ações e reações a fatos e eventos, comportamentos e atitudes [...]", constituindo-se como uma significativa ferramenta para o conhecimento das representações e percepções "[...] prevalentes no trato de uma dada questão por pessoas que partilham alguns traços em comum, relevantes para o estudo do tema visado". Em sintonia com esses pressupostos, então, foi que se considerou a potencialidade dos grupos focais.

Foram realizados sete encontros, os quais ocorreram, semanalmente, durante um período de dois meses em sala disponibilizada pela escola, com duração de 40 minutos para cada grupo. A complexidade do processo de geração de dados com crianças merece ser comentada: é preciso planejar, elaborar materiais evocadores que suscitem envolvimento e participação nas propostas investigativas. Rocha (2008) assinala que, em se tratando de pesquisa com crianças, a lógica da comunicação, para conhecer seus pontos de vista, não pode centrar-se nem apenas na oralidade e muito menos na escrita; em razão disso, há necessidade de cruzar fala ou diálogos em grupos com outras linguagens, como as presentes em desenhos e fotografias. Considerando esse entendimento, fizemos escolhas metodológicas que tiveram como objetivo ampliar possibilidades de atribuição de sentidos pelas crianças, a fim de que pudessem se valer de diferentes linguagens para dar forma às suas ideias.

A temática do primeiro encontro versou sobre o contexto familiar e social das crianças, suas rotinas e espaços de circulação. Foi realizado um jogo em que elas retiravam fichas com imagens e os seguintes tópicos, sobre os quais poderiam falar livremente: onde mora, com quem mora, o que você faz em casa quando não está na escola, o que os familiares fazem em casa quando não estão trabalhando/na escola, o que você faz fora de casa quando não está na escola, o que os familiares fazem fora de casa quando não estão trabalhando/na escola.

O segundo e o terceiro encontros tiveram por temática a leitura realizada em casa e os materiais utilizados para tanto, tendo em vista a tríade de Chartier (2004): textos, suportes e práticas de leitura. Previamente, havíamos solicitado que as crianças trouxessem de casa materiais que fossem lidos por elas ou por outro familiar/morador. Uma criança por vez, então, apresentava seus materiais de leitura: nesse momento, havia interação entre os participantes que estavam curiosos para ver o que os colegas haviam trazido. Convidamos, também, as crianças a desenharem os materiais presentes na sua casa, os quais consideravam possível de serem lidos. A proposta igualmente solicitava a identificação dos materiais feita, por escrito, 
pelas crianças. Tais registros contabilizaram doze produções gráficovisuais que compõem o conjunto de dados.

Â medida que as crianças finalizavam suas produções, cada uma era chamada a participar de uma conversa sobre os desenhos e os materiais trazidos, o que se configurou de forma semelhante a uma entrevista, sendo uma estratégia metodológica secundária em relação ao grupo focal. Nosso objetivo era compreender como a criança explorava cada material no ato de leitura; assim, ela narrava sobre cada um dos objetos: como, onde e com quem usavam. Neste ínterim, realizávamos questionamentos com o objetivo de esclarecer o contexto de uso dos materiais de leitura selecionados. Por exemplo: onde vocês guardam os livros de história? Alguém mais lê esses livros? Quando? Somente a mãe lê a Bíblia em casa? Ela leva para outro lugar? Por que estes textos estão marcados? Quem fez isso? Com essas perguntas, tínhamos a intenção de identificar, do ponto de vista da criança, a funcionalidade dos textos.

Os dois encontros seguintes (quarto e quinto) tiveram o mesmo funcionamento dos anteriores, com a mudança da temática para as práticas de escrita. Os últimos encontros (sexto e sétimo) focalizaram os espaços de circulação das crianças a partir da análise de materiais de leitura e escrita recolhidos na comunidade.

Todos os encontros foram gravados por meio de áudio e imagem (fotografias e vídeos), bem como foram feitas transcrições degravadas. ${ }^{2}$ Tais transcrições compuseram um banco de dados, assim como as imagens advindas dos encontros. Após cada sessão de grupo focal, era redigido um diário de campo no qual descrevíamos os encontros e registrávamos impressões pertinentes.

Em relação aos aspectos éticos, a participação das crianças ocorreu mediante a assinatura de cada uma de um termo de assentimento, redigido em linguagem considerada adequada à compreensão do grupo, e do termo de consentimento assinado pelos pais ou responsáveis. Houve a troca dos nomes dos participantes por fictícios na transcrição dos eventos e a exclusão dos nomes nas produções, caso as crianças os tivessem registrado.

De posse desse conjunto de dados referentes à leitura, realizamos a tabulação a partir dos materiais apresentados. A primeira coluna do quadro diz respeito ao material; a segunda, à imagem; e a terceira refere-se à transcrição da interação da criança com a pesquisadora no momento da apresentação de cada material, tal como se vê no exemplo abaixo: 
QUADRO 1. Exemplo de Kauã para tabulação dos materiais de leitura apresentados

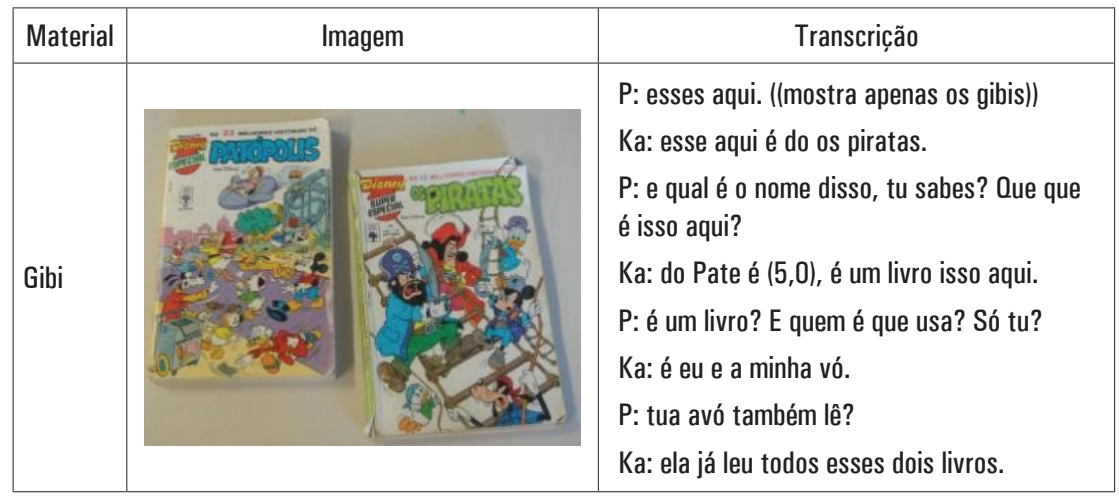

Fonte: Organizado pelas autoras

Considerando a organização dos dados sob esta configuração, é que procedemos à análise, pautada pela identificação das práticas de leitura mais recorrentes e de outras mais singulares do grupo em questão. Cabe salientar que dados empíricos referentes a todas as crianças participantes da pesquisa foram contemplados ao longo das análises.

Como uma primeira incursão aos dados, exemplificamos aqui a potencialidade de aproximar a faceta linguística da alfabetização às práticas de leitura. A pausa assinalada na transcrição acima $(5,0)$ e o seguimento da resposta de Kauã dão indícios de que o menino iniciou a leitura do título do gibi como "Pate" supostamente pela associação ao nome Pateta, personagem ilustrado na capa. Inferimos que, ao perceber que a segunda sílaba pronunciada "Pate" não era a mesma escrita no título "Patópolis", fez a pausa na tentativa de revisar, de forma silenciosa, sua leitura. Como não conseguiu avançar, provavelmente por não ter habilidades suficientes de conversão grafema-fonema, abandonou sua tentativa de leitura e utilizou o nome "livro" duas vezes para identificar o material, denominação generalizante que irá reaparecer nos dados e que a ela atribuímos a função "guarda-chuva", discutida ao longo deste trabalho.

\section{PRÁTICAS DE LEITURA}

Em outra ocasião (PICCOLI, 2010), já fizemos a distinção entre os conceitos de prática e evento e, neste texto, a ideia de "práticas de leitura" é utilizada como um desdobramento da noção de "práticas de letramento" difundida por Street em várias publicações, dentre elas o compêndio produzido com Lefstein (STREET; LEFSTEIN, 
2007). Nessa publicação, os autores elencam leitura, escrita, fala e audição - essas duas últimas compreendendo oralidade - como elementos constitutivos do letramento, daí nossa opção pelo uso de "práticas de leitura", no sentido de circunscrever o foco deste texto. Entendemos, assim, que as práticas são locais e situadas e que os usos da língua escrita adquirem sentido, então, quando envoltos em seus contextos de origem. Considerando que as práticas são observáveis em eventos mediados por materiais escritos e que o texto presente nas práticas desencadeia interações entre os participantes, entendese que é possível conhecer as práticas das pessoas, o que elas fazem com os textos e materiais e quais significados atribuem às atividades de leitura e de escrita. Para além da descrição de eventos e busca de regularidades, Street (2010) argumenta que a noção de práticas de letramento permite empreender reflexões que conduzem a implicações para políticas de educação e, estendendo essa perspectiva, citamos igualmente os currículos e as práticas escolares.

É o delineamento conceitual acima exposto, portanto, que guia os eixos analíticos construídos com base no exame das recorrências encontradas no material empírico, quais sejam: a variedade de materiais e práticas de leitura apontada pelos sujeitos participantes, o protagonismo da criança-leitora em seu contexto familiar, a perspectiva das crianças sobre os gêneros e os suportes de leitura.

\section{VARIEDADE DE MATERIAIS E PRÁTICAS DE LEITURA}

Conforme a primeira coluna do quadro 1, agrupamos os materiais de leitura, trazidos ou desenhados, com base nas nomeações atribuídas pelas crianças. Entretanto, por vezes, foi necessário complementar tais denominações para garantir a diferenciação dos materiais entre si. Deste modo, foi gerado o quadro-síntese abaixo (Quadro 2), em que a ocorrência se refere ao número de crianças que apresentou determinado material, não à quantidade de objetos em si: 
QUADRO 2. Quantificação dos materiais de leitura apresentados

\begin{tabular}{|c|c|c|c|}
\hline Materiais & Ocorrência & Materiais & Ocorrência \\
\hline Livro (literários - textos narrativos) & 11 & Carrinho & 1 \\
\hline $\begin{array}{l}\text { Embalagem (bebidas, alimentos, } \\
\text { materiais de higiene) }\end{array}$ & 10 & Cinto & 1 \\
\hline Bíblia & 6 & Diário & 1 \\
\hline Jornal & 6 & Dicionário & 1 \\
\hline Calendário & 4 & Dvd & 1 \\
\hline Cartinha de jogo & 4 & Enfeite & 1 \\
\hline Imã de geladeira & 3 & Espelho & 1 \\
\hline Álbum de figurinhas & 2 & Fotografia & 1 \\
\hline Bilhete & 2 & Harpa - livro de cânticos & 1 \\
\hline Carta & 2 & Jogo (Banco Imobiliário) & 1 \\
\hline Gibi & 2 & Lápis & 1 \\
\hline Papel & 2 & Livro colorido de pais & 1 \\
\hline Quadro & 2 & Livro de Deus & 1 \\
\hline Revista & 2 & Livro de Jesus & 1 \\
\hline Roupa & 2 & Livro didático & 1 \\
\hline Telefone & 2 & Mapa & 1 \\
\hline Televisão & 2 & Palavra cruzada & 1 \\
\hline Agenda & 1 & Pilha & 1 \\
\hline Almanaque & 1 & Rádio & 1 \\
\hline Ar condicionado & 1 & Secadora de roupa & 1 \\
\hline Bula de remédio & 1 & & \\
\hline
\end{tabular}

Fonte: Organizado pelas autoras.

Buscamos valorizar o que as crianças nos apontaram como sendo objetos passíveis de leitura; dentro desse conjunto, destacamos a presença dos materiais recorrentes no Quadro 2, quais sejam: livros da biblioteca escolar, embalagens, jornais e Bíblia. Também, 
há os menos associados a suportes convencionais e menos utilizados recorrentemente nas práticas escolares, a exemplo de ímãs de geladeira, cinto, espelho, pilha. Tais suportes Marcuschi (2003) nomeia como incidentais e serão ainda aqui discutidos.

Um olhar ao contexto de tais materiais nos leva à identificação de "esferas de circulação", dimensão advinda dos estudos sobre gêneros discursivos. Ribeiro (2004), em clássico sobre práticas de letramento de jovens e adultos, refere-se a essas esferas como sendo as da vivência cotidiana em que práticas de leitura e escrita podem estar presentes. Em nossa pesquisa, encontramos materiais que se encaixam nas esferas apontadas pela autora: a esfera doméstica (embalagens de produtos, jornais, revistas, calendário, correspondências, equipamentos domésticos, peças do vestuário, fotografias, aparelhos telefônicos, bulas de remédio); a esfera do lazer (jogos, cartinhas, álbum de figurinhas, gibis, palavras cruzadas); a esfera escolar (livro didático, agenda, dicionário, mapa); a esfera religiosa (Bíblia, livro de Deus, livro de Jesus, harpa - livro de cânticos). Ainda que os materiais mencionados pudessem estar inseridos em mais de uma esfera de circulação, nosso critério de inserção justifica-se pelas práticas de leitura associadas àqueles materiais, as quais foram acessadas por meio das nossas interações com as crianças. Algumas dessas práticas serão retomadas em outro tópico.

Ainda no que tange à questão da variedade de materiais, mais dois aspectos chamaram atenção em relação às crianças: 1) a atitude de pesquisa, supostamente partilhada com as famílias, após a solicitação da pesquisadora para que trouxessem materiais de leitura, a exemplo de Felipe (Figura 1) e Kauã (Figura 2) nas imagens e nos excertos do diário de campo abaixo, fazendo-nos considerar como relevante tal envolvimento familiar tanto pela busca conjunta, quanto por nos possibilitar acesso a uma diversidade significativa desses materiais; 2) a originalidade do léxico manifestada na nomeação dos itens apresentados, como demonstrada na produção gráfico-visual de Beatriz (Figura 3). Esses aspectos, para nós, representam atitudes de inserção efetiva no mundo da escrita, revelando interesse em "ler" com uma finalidade específica, além de uma capacidade considerável de diferenciação no que diz respeito àquilo que é passível de leitura. 
FIGURA 1. Materiais de leitura apresentados por Felipe

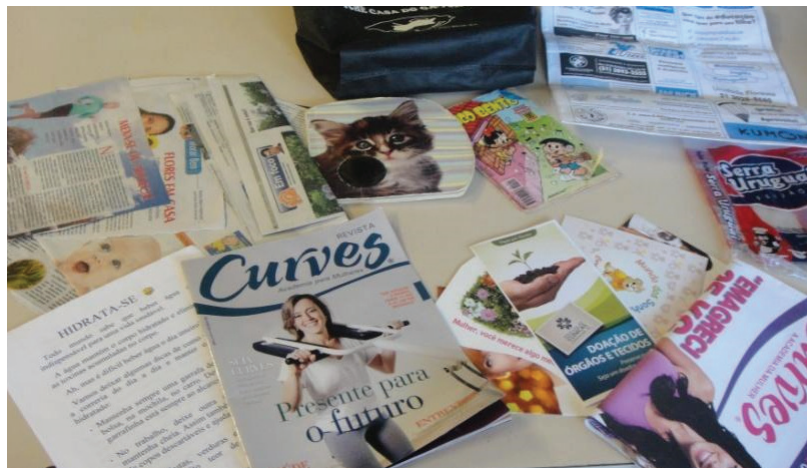

Fonte: Acervo de imagens da pesquisa

FIGURA 2. Materiais de leitura apresentados por Kauã

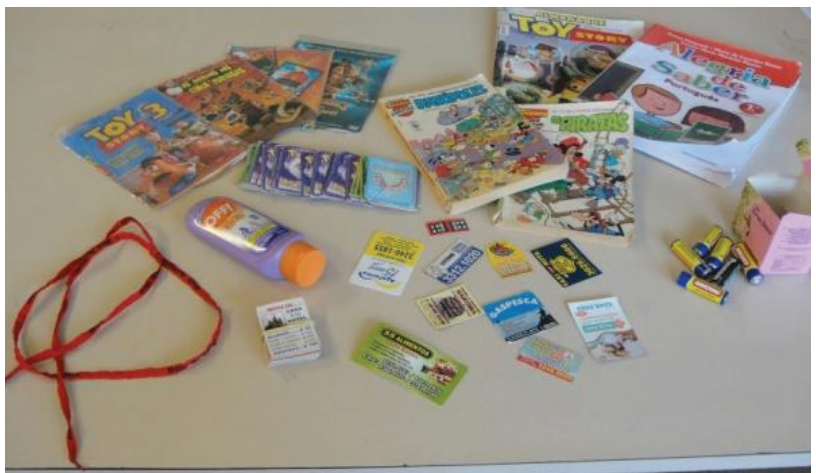

Fonte: Acervo de imagens da pesquisa

Felipe levou uma grande variedade de objetos, que, após apresentados, chegamos à conclusão de que a mãe tinha se envolvido bastante na proposta e realizado a busca de muitos deles. Ele nos trouxe vários recortes de revistas e jornais sobre corpo e saúde, justificando que eram da mãe porque ela trabalha em uma academia. Assim como Felipe, Kauã também trouxe uma quantidade significativa de objetos, possivelmente a família se envolveu muito com o que estávamos buscando.

(Excerto 1 - Diário de campo) 
FIGURA 3. Produção gráfico-visual de Beatriz sobre materiais de leitura

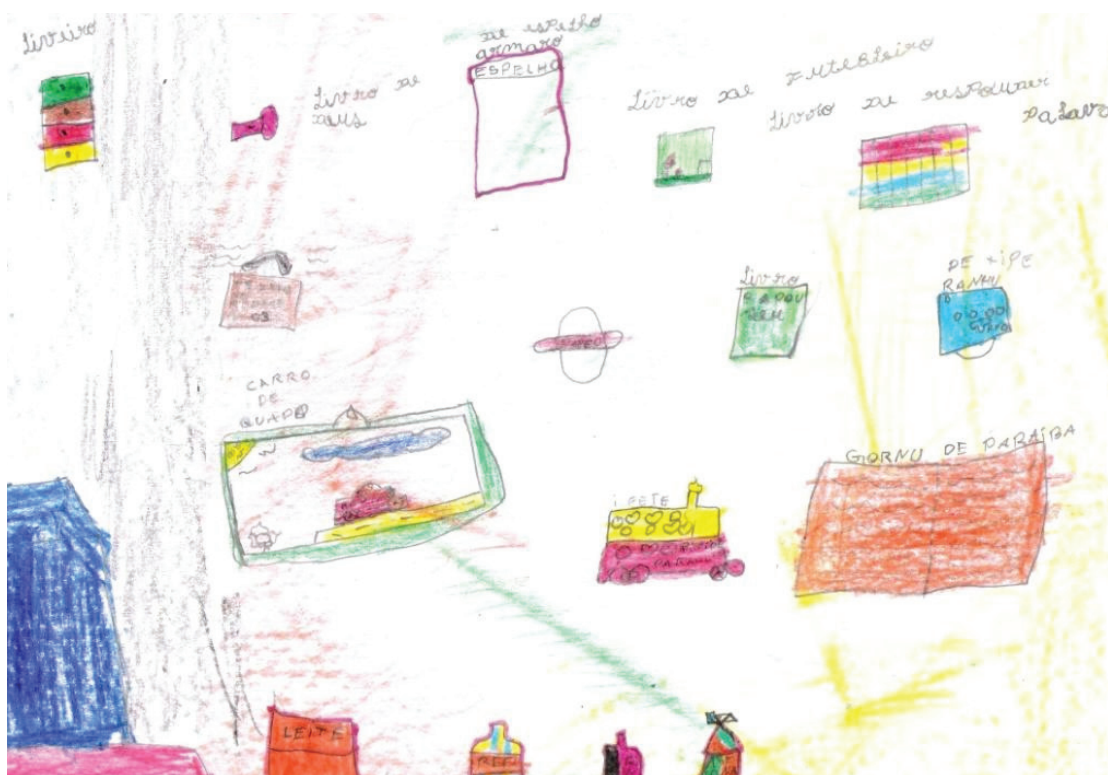

Fonte: Acervo de imagens da pesquisa

Diferentemente dos meninos, Beatriz trouxe apenas algumas embalagens, mas investiu no detalhamento de sua produção gráfica, representando muitos materiais de leitura presentes na sua casa. Para permitir o acesso a esta variedade, no excerto do diário de campo apresentado a seguir, registramos a produção da criança, ao lado, a intenção de escrita verbalizada em entrevista e os comentários que fez acerca do uso desses materiais, sendo destacado com aspas quando algum trecho de fala foi transcrito. Fizemos um exercício de leitura e inferência para atribuir sentido aos nomes "curiosos" dados por Beatriz aos materiais - muitos deles evocando sua função, tais como "livreiro" e "livro de responder palavras" - e aos usos compartilhados por tantas pessoas da família, já que, além dos pais, a criança referiuse a muitos irmãos e irmãs de diferentes idades. Foi surpreendente, para nós, a diversidade de materiais presente na casa da menina e as variadas práticas exercidas pela família. 
livro rapouseu - livro Rapunzel: a irmã mais velha lê para fazer a irmã pequena dormir;

ifete - enfeite;

gornu de paraiba - Jornal de Paraíba: é lido pelo pai e pela mãe, provavelmente é um jornal comunitário;

de xipe ranhu - rádio de chip: o irmão escuta música nele, ganhou do pai; de espelho armaro - armário de espelho: nele "todo mundo escreve recado";

liveiro - livreiro: gaveta onde guardam livros, como "o da bruxa, do Mickey, do carro", ela e as irmãs mais velhas leem os livros e a mãe lê para a irmã menor;

livro de Deus: "é um livro que tá escrito Deus cuida da gente", a mãe lê; telefone redeceal 03 - telefone residencial casa 03;

carro de quado - quadro de carro;

leite - caixa de leite;

refi - garrafa de refri;

$\mathrm{RN}$ - garrafa de água;

asetona - acetona;

papeu - papel;

livro de futebleiro - livro de futeboleiro: provavelmente o álbum de figurinhas do campeonato gaúcho de futebol;

livro de respouder palavra - livro de responder palavra: supostamente revista de palavras cruzadas.

(Excerto 2 - Diário de campo)

Consideramos relevante examinar ao menos um aspecto sobre a produção escrita de Beatriz que se relaciona à leitura. Miranda (2017, p. 44) defende ser primordial reconhecer a motivação dos erros para compreender as estratégias utilizadas pelas crianças, as quais giram em torno de dois fatores: "erros relativos à complexidade do sistema ortográfico do português (arbitrariedade e contextualidade) e erros relacionados a aspectos fonético-fonológicos (segmental ou prosódico)". Na produção de Beatriz, a palavra "livro" foi escrita corretamente quatro vezes. Nota-se, porém, que o mesmo não ocorreu em todos os outros casos em que o grafema $\mathrm{R}$ se posiciona, 
na sílaba, entre uma consoante e uma vogal: "liveiro", "quando" e "refi". Miranda e Matzenauer (2010) afirmam que todas as sequências maiores que a estrutura canônica CV (consoante-vogal) podem acarretar hesitações que irão direcionar as escolhas gráficas das crianças, resultando em formas distintas das convencionadas pelo sistema. Nesses erros fonológicos relacionados à grafia de estruturas silábicas mais complexas, a criança tende a reduzir a sílaba CCV ao padrão CV: é o que acontece na produção de Beatriz. O acerto da palavra "livro" parece estar mais relacionado, então, à alta frequência da palavra, apontando para sua existência, como representação ortográfica, no léxico mental da criança e não pelo conhecimento da estrutura das sílabas compostas por CCV. O domínio dessa palavra decorre então, provavelmente, da sua leitura frequente em diferentes contextos vinculados às práticas leitoras das quais participa. Esse dado também corrobora a preponderância da nomeação "livro" já referida nesta pesquisa como um "guarda-chuva", abrigando sob ele distintos suportes e gêneros.

\section{CRIANÇA PROTAGONISTA DA LEITURA}

Neste eixo, apontaremos situações em que as crianças demonstram "certa autonomia" para exercer as práticas de leitura. Dizemos "certa autonomia" porque elas ainda estão em processo de aquisição das habilidades de decodificação e compreensão do texto escrito; entretanto, apresentam gestos leitores e rotinas de leitura que as colocam em uma posição de protagonismo dessas práticas em seu ambiente familiar. Entendemos que essa iniciativa decorre de motivações significativas para a leitura e para a escrita, como exemplifica Solé (2009): ver adultos que sejam referências para elas lendo ou escrevendo, acompanhar a leitura em pequenos ou grandes grupos, tentar e sentir-se aprovadas em seus ensaios de leitura. É com este olhar que apresentaremos excertos de conversas realizadas com três crianças participantes do estudo. Iniciamos com Vinícius: 
P: e de quem é essa Bíblia?

Vi: é minha.

P: é tua? E cada um na tua casa tem uma?

Vi: ((concorda))

P: quem mais tem Bíblia na tua casa?

Vi: meu irmão, o meu outro meu irmão, ã, minha mãe, o meu pai, ele deu a dele pro meu irmão Igor e agora vai comprar hoje uma nova pra ele.

P: e é só em casa que tu usa a Bỉblia?

Vi: não, na igreja também. Também tem a escolinha.

P: tem a escola da igreja?

Vi: escolinha, daí a gente vai lá ler a Bíblia, a gente brinca, a sora conta história.

P: e tu lê a Bỉblia na escolinha também?

Vi: ((sinaliza positivamente))

P: mostra como tu lê a Bíblia então, será que tu pode ler um pedacinho?

Vi: posso. Então espera aí. ((folheia a Bíblia))

Vi: tá, e vi desceram o céu um anjo tinha a chave do abismo e uma grande cabeça na sua mão, ele prendeu o dragão e an antiga serpente que e o guiava e satanás e amarrou.

$P$ : e que que tu entendeu disso que tu leu?

Vi: nadinha.

P: não entendeu? E vocês conversam sobre o que vocês leram na escola ou em casa, quando leem a Bíblia?

Vi: ((sinaliza negativamente))

P: não? E tem umas marcações na tua Bíblia, me mostra, tem umas escritas, né?

V: tem. ((abre a Bíblia e mostra a última página e a contracapa onde tem escritas e desenhos))

P: que que é isso?

Vi: os desenhos.

P: tu que fez?

Vi: ((sinaliza positivamente)) 
P: e tu fez quando esses desenhos?

Vi: quando eu ganhei minha Bíblia.

$\mathrm{P}:$ isso, quem é que marcou essas coisas assim ((aponta as marcações))

Vi: eu, eu leio.

P: ah, quando tu lê, tu marca?

Vi: eu já até li um monte aqui. ((folheia a Bíblia mostrando as marcações))

P: tudo que tu leu tá marcado?

Vi: aham.

P: ah, e tá marcado com cores diferentes.

Vi: é, às vezes eu marco com o marcador e às vezes com caneta, só que o marcador gastou, aí não tem mais.

(Excerto 3 - Transcrição)

Esse excerto de diálogo possibilita refletir sobre as práticas de leitura da esfera religiosa e sua função dentro da família de Vinícius. A compreensão leitora por parte da criança, nesse exemplo, fica em segundo plano, tendo em vista que a prática da leitura oral ganha mais importância porque tal habilidade é condição de pertencimento tanto na família quanto na comunidade religiosa. Essa afirmação se sustenta na resposta de Vinícius, que, ao ser perguntado sobre o sentido da leitura ("e que que tu entendeu disso que tu leu?"), respondeu "nadinha", manifestando sua incompreensão do texto bíblico lido para a pesquisadora. Por outro lado, salientamos a fluência na leitura oral do menino, praticada, como ele mesmo cita em outro excerto, ao menos três vezes por semana. O empenho em ler o complexo léxico da Bíblia, provavelmente, o auxilia no desenvolvimento da "consciência grafofonêmica" no processo de decodificação (SOARES, 2016), requisito para a leitura tanto oral quanto silenciosa.

No intuito de nos aproximarmos um pouco mais das complexidades presentes nos dados, se faz necessário, nesse momento, um investimento conceitual nos aspectos linguísticos da alfabetização, buscando entender as estratégias das crianças ao lerem as palavras e os textos presentes. Acerca da leitura de palavras, o modelo já comprovadamente validado no Brasil, o de dupla rota, é assim sintetizado por Soares (2016, p. 256): “[...] pode ocorrer ou pelo processo de decodificação grafema-fonema - rota fonológica ou sublexical -, ou pelo reconhecimento visual direto da ortografia de palavra conhecida, 
'arquivada' em um léxico mental que reúne representações de palavras familiares - rota lexical", a qual também pode ser nomeada como visual ou ortográfica. Soares (2016) detalha os efeitos, identificados nas pesquisas, das características das palavras sobre a leitura e a escrita: o efeito da lexicalidade, da extensão, da vizinhança, da frequência e da regularidade. Nos dados arrolados nesta seção, destacamos o funcionamento das duas rotas nas leituras das crianças e como se relacionam com alguns dos efeitos das características das palavras.

Além da decodificação e do reconhecimento de palavras, ler envolve a compreensão de textos: é o que afirma Spinillo (2013) ao caracterizar essas duas instâncias complementares e indissociáveis da leitura. Para a autora, a compreensão assume um caráter amplo, espraiando-se pelo texto como um todo e pressupondo relações entre informações nele veiculadas e o conhecimento de mundo do leitor. No caso de Vinícius, a incompreensão se deu, provavelmente, pelo fato de as habilidades valorizadas na esfera religiosa não se relacionarem à atribuição de sentidos pelo leitor. Soares (2016, p. 254) alerta que, apenas quando a criança se torna capaz de construir representações ortográficas das palavras, sendo a decifração e cifração rápidas e corretas, "[...] é que se pode considerar que ela realmente adquiriu habilidades de leitura e escrita de palavras, necessárias, ainda que não suficientes, para que alcance competência em leitura e produção fluentes de textos.”. O reconhecimento rápido e correto de palavras de Vinícius, feito pela rota lexical, atende a demandas de um contexto específico, o religioso, mas essas habilidades não são suficientes para sua participação efetiva em grande parte das situações escolares e sociais de leitura nas quais a compreensão do texto é requisito. Para tanto, o texto precisa se tornar, com regularidade, objeto de reflexão e análise na escola, por meio de tratamentos didáticos específicos, envolvendo diferentes capacidades.

A velocidade e a correção da leitura de Vinícius permitem apontar que a criança já construiu um variado léxico mental que possibilita o predomínio do uso da rota lexical, demonstrando, para tanto, domínio das regras de correspondências grafofônicas. Morais, Leite e Kolinsky (2013, p. 23) definem léxico mental ortográfico como "conjunto das representações mentais estruturadas da ortografia das palavras que conhecemos da língua e que armazenamos, de maneira organizada, no nosso cérebro". É a alta frequência das palavras do contexto religioso em questão que possibilita que Vinícius as tenha incorporado ao seu léxico gráfico e mental, o que resultou em uma leitura relativamente rápida e praticamente sem hesitações. Os deslizes 
de Vinícius se deram em apenas duas situações: uma troca na leitura da palavra "cabeça" ao invés do original "cadeia" e ao ler a palavra "antiga", segmentando a primeira sílaba "an", mas logo recompondo sua integralidade. O fato de Vinícius ter lido "cabeça" ao invés de "cadeia" parece ter mais relação com o efeito da vizinhança e a semelhança visual entre palavras - já que há o mesmo número de letras entre as duas e a troca apenas de dois pares de grafemas - do que em relação ao efeito de regularidade, que está relacionado a erros de decodificação. Além desse argumento, outro revela o uso da rota lexical nesse caso: o fato de Vinícius demonstrar estar bastante avançado em relação ao desenvolvimento da consciência grafofonêmica.

Ao analisarmos a materialidade do objeto em si, a Bíblia (Figuras 4 e 5), percebemos que há tanto inscrições e desenhos nas páginas iniciais e finais do livro (onde há espaços em branco), quanto destaques com distintos instrumentos de escrita, ora marca-textos, ora caneta esferográfica. Nesse sentido, Vinícius nos dá pistas de suas práticas leitoras, ao sinalizar trechos já lidos e, supostamente, considerados importantes pelos demais integrantes da família e da comunidade. Chartier (2009, p. 91-92), ao escrever sobre a multiplicidade de abordagens da leitura, afirma que as experiências individuais " [...] são sempre inscritas no interior de modelos e de normas compartilhadas. Cada leitor, para cada uma de suas leituras, em cada circunstância, é singular. Mas esta singularidade é ela própria atravessada por aquilo que faz que este leitor seja semelhante a todos aqueles que pertencem à mesma comunidade.”. Em outra ocasião, o mesmo autor (2000) alerta sobre a dificuldade de rastrear as práticas de leitura, uma vez que são poucos os vestígios deixados pelos leitores dos mais diversos textos. Contrariamente a esse alerta, no caso deste menino, há indícios evidentes da leitura vivenciada a partir da observação de comportamentos específicos de outros leitores, possivelmente da esfera religiosa (destacar trechos, fazer anotações nas margens...). 
FIGURA 4. Bíblia apresentada por Vinícius com trechos destacados

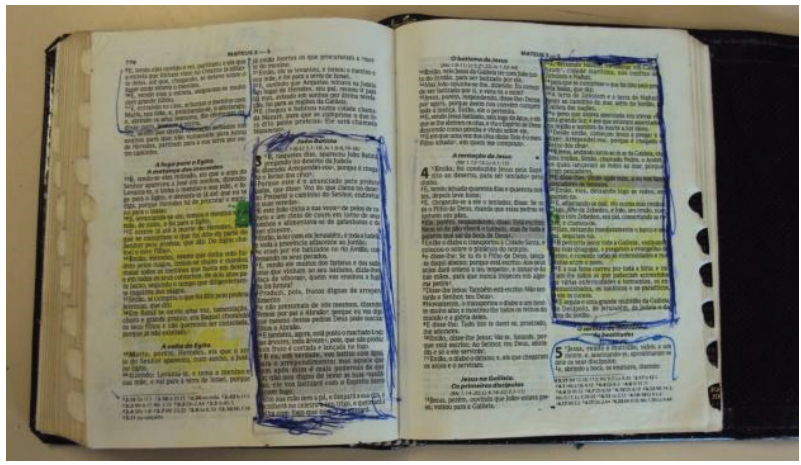

Fonte: Acervo de imagens da pesquisa

FIGURA 5. Bíblia apresentada por Vinícius com desenhos e inscrições

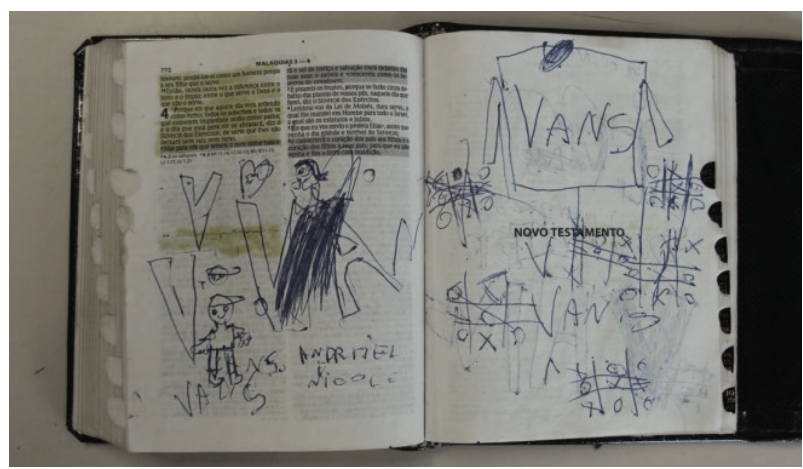

Fonte: Acervo de imagens da pesquisa

No que se refere aos desenhos, Vinícius salienta que os produziu quando ganhou sua Bíblia. Essa prática gráfica nos remete à ideia de apropriação do objeto de leitura pelo menino, tornando-o "próprio", "próximo", por meio das marcas de identificação. $\mathrm{Na}$ imagem (Figura 5), vemos desenhos de pessoas e a reprodução recorrente da escrita VANS, uma marca de produtos esportivos para a prática de skate, e ainda uma função inusitada, tendo em vista o tipo de suporte: o registro do jogo da velha. Tais elementos nos levam a refletir sobre uma infância multifacetada, vinculada aos ritos religiosos, mas também observadora de objetos de consumo. Em outras palavras, reconhecemos uma mescla de eventos em torno dessas práticas, a exemplo da inscrição do jogo da velha, sinalizando, também, a dimensão lúdica. Ou seja, há um entrecruzamento de práticas culturais presenciadas e, possivelmente, vividas pela criança 
que pode ser visibilizado na materialidade do objeto de leitura. $\mathrm{Na}$ sequência, prosseguimos com Kauã.

P: e em casa tu tem livro?

Ka: tenho.

P: tu tem? Quais tu tem?

Ka: uns de, eu conto as histórias pra minha irmã.

P: que idade ela tem?

Ka: cinco meses.

P: tu já contou história pra ela? Que tipo de história tu conta?

Ka: ã $(3,0)$ a do, a $(5,0)$.

P: tu conta história inventada ou tu lê no livro a história?

Ka: ã, no livro.

P: tu lembra o nome de um dos livros? E sobre o que que é a história, tu lembra?

Ka: do patinho.

P: e tu tem mais algum livro que tu lê pra tua irmã?

Ka: não.

P: e quando tu lê pra ela?

Ka: ã, eu leio quase todo dia pra ela, quando eu chego da escola, fico olhando pra ela.

P: ah, e aí tu lê?

Ka: aham.

P: e ela gosta?

Ka: gosta.

P: como é que tu sabe que ela gosta?

Ka: ela fica rindo.

P: e tu mostra as figuras pra ela?

Ka: mostro.

P: como tu conta, mostra pra mim.

Ka: eu leio todas as palavras, leio toda a página e daí eu mostro pra ela.

P: e o livro é teu ou é dela? 
Ka: mostro.

P: como tu conta, mostra pra mim.

Ka: eu leio todas as palavras, leio toda a página e daí eu mostro pra ela.

P: e o livro é teu ou é dela?

Ka: também não.

(Excerto 4 - Transcrição)

A atitude de leitor de Kauã permite refletir sobre as situações reais de leitura e suas funções no contexto doméstico. Lembramos novamente o protagonismo infantil exercido do lugar de quem "conta história" para alguém, com o objetivo de interagir com uma criança menor - interação esta mediada pelo objeto livro de literatura infantil - e, também, de proporcionar prazer, já que Kauã infere que sua irmã aprecia ouvir histórias porque "ela fica rindo". Cabe mencionar que a prática da contação de histórias ao bebê, realizada quase que diariamente, conforme o menino, é desempenhada não pelos adultos, mas pelo irmão mais velho, cujos gestos leitores, supostamente, foram inspirados em práticas exercidas por outros adultos: "eu leio todas as palavras, leio toda a página e daí eu mostro pra ela”.

Nessa direção, Ferreiro argumenta que os primeiros leitores são formados nas famílias quando há livros e leitores ao seu redor: "Estou enfatizando que os leitores são formados desde o início e que nada pode substituir uma primeira experiência amistosa, corpo a corpo, com a letra impressa materializada em um livro." (FERREIRO, 2013, p. 442). A pesquisadora alerta que, quando essas experiências não ocorrem na família, a escola pública deve ser o lugar para que as crianças tenham acesso a livros variados, atraentes e desafiantes. Sem perspectiva de polarizações, o que veremos a seguir, com Laura, é um misto desses pressupostos que aliam família e escola.

P: então Laura, mostra. O que tu trouxe?

Lau: trouxe o livro da bruxa e o livro do Zac Power. (Figura 6)

P: e de onde são esses livros?

Lau: são da biblioteca.

P: e tu retirou? Tu escolheu? 
Lau: ((sinaliza positivamente))

P: e quem lê eles?

Lau: esse daqui foi o meu pai ((aponta para o do Zac Power)) e esse daqui eu li ((aponta para o da bruxa))

P: tu tirou pro teu pai esse? ((aponto para o do Zac Power))

Lau: não, eu tirei pro meu pai ler pra mim e peguei esse, esse eu li sozinha ((aponta para o da bruxa))

P: esse tu lê sozinha, consegue ler um pedacinho pra mim, então?

Lau: bruxa, bruxa por favor venha a minha festa. Obrigado, irei sim se você convidar o gato.

P: então continua lendo.

Lau: gato, gato por favor venha a minha festa. Obrigado, irei sim se você convidar o $(3,5)$ ess...pantalho

Lau: espantalho, espantalho por favor venha a minha festa. Obrigado irei sim se você convidar a coruja. Coruja, coruja por favor venha a minha festa. Obrigado, eu irei sim se você convidar a árvore.

[a criança continuou lendo até finalizar a história]

Lau: Obrigado, irei sim se você convidar as crianças. Crianças, crianças por favor venham a minha festa. Obrigado, irei sim se você convidar a bruxa. Aí começa tudo de novo.

P: e tu gostou desse livro por quê?

Lau: porque é legal, é tipo uma frase.

P: e tu já sabe ler tudo, né? Eu percebi. Tu já leu quantas vezes esse livro? Lau: duas e três com essa.

P: e tu já conseguiu ler tudo assim! E esse aqui ((aponta para o do Zac Power)), quantas vezes tu já leu?

Lau: nenhuma, só meu pai.

P: o teu pai, ele leu até onde?

Lau: ele leu acho que até aqui ((folheia o livro e aponta uma determinada página))

P: ah, e tu tá gostando da história? Sobre o que é?

Lau: é (2,0) um negócio que eu não me lembro, me esqueci. 
P: e o pai lê quando?

Lau: de noite.

(Excerto 5 - Transcrição)

FIGURA 6. Livros apresentados por Laura

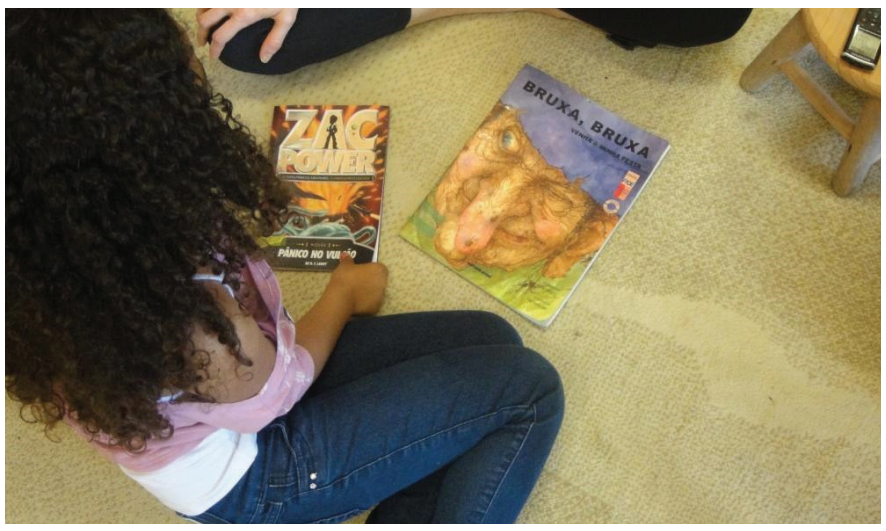

Fonte: Acervo de imagens da pesquisa

FIGURA 7. Laura lendo o livro "Bruxa, bruxa, venha a minha festa"

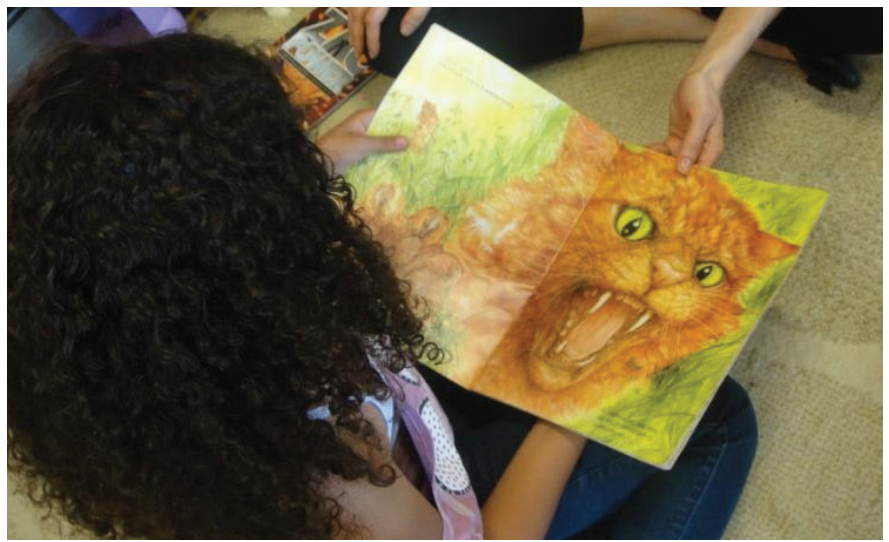

Fonte: Acervo de imagens da pesquisa

Não destoando dos demais colegas do seu grupo focal, Laura trouxe apenas livros retirados na biblioteca. A nosso pedido, a menina leu sozinha o livro "Bruxa, bruxa, venha a minha festa". No começo, apresentava voz tímida e gaguejava; aos poucos, foi ficando 
desenvolta e leu integralmente o texto, respeitando sua sequência. O livro é propício para leitores iniciantes, pois apresenta uma narrativa em que a estrutura sintática se repete, alterando-se apenas com a troca dos personagens, conforme se pode identificar nos trechos sublinhados na transcrição acima. Laura parecia ter domínio de toda a parte em repetição e investia em estratégias de leitura diferenciadas quando precisava identificar o novo personagem a ser convidado, o qual, na página seguinte, aparecia ilustrado (Figura 7).

Ehri (2013) explica que, quando as palavras se tornam familiares e são armazenadas na memória, passam a ser lidas por "reconhecimento automatizado", já que sua leitura foi praticada pelo leitor. No caso de Laura, é a própria criança que confirma a realização dessa prática ao afirmar que aquela era a terceira vez que lia o livro: "duas e três com essa". Tais palavras, portanto, se tornaram familiares e foram armazenadas na memória, o que conferiu características de precisão e rapidez à leitura.

Nessa leitura de Laura, observa-se o funcionamento paralelo das duas rotas: enquanto as palavras frequentes em livros literários (bruxa, gato, coruja) foram lidas provavelmente pela via lexical, à palavra espantalho foi necessário lançar mão da via fonológica, ou por ser pouco frequente ou pela própria extensão em relação às outras. É possível observar o tempo demandado pela criança ( 3,5 segundos) para subvocalizar a palavra espantalho, pronunciada em tom ascendente, sinalizando dúvida na primeira sílaba (ess) e, posteriormente, realizando a complementação do vocábulo (pantalho). Esse tempo de reação vocal e a subvocalização podem ser entendidos, segundo Soares (2016), como indícios de leitura pela rota fonológica. No caso de Laura, é possível tecer aproximações ao efeito de frequência e da extensão das palavras. Assim, o efeito da extensão da palavra e, nesse caso, da sua baixa frequência, podem ser relacionados aqui à leitura pela rota fonológica, características associadas sobretudo ao início da aprendizagem da língua escrita, como concluem pesquisas com crianças brasileiras referidas por Soares (2016). A diferenciação feita pela pesquisadora, a seguir, além de corroborar os dados acima, permite-nos tecer implicações pedagógicas que serão discutidas ao final deste texto.

Assim, desde muito cedo, a criança em processo de alfabetização memoriza e arquiva em seu léxico mental, ortográfico e semântico, palavras que vê repetidamente escritas no material didático e nos livros de literatura infantil com que convive e interage, o que lhe possibilita o uso da rota lexical, e desse modo uma leitura e escrita em geral mais rápida e correta dessas palavras. Por outro lado, palavras de baixa frequência demandam em geral leitura e escrita pela rota fonológica, o que aumenta o tempo de reconhecimento e de codificação, e pode conduzir a erros de correspondências grafofonêmicas e fonografêmicas. (SOARES, 2016, p. 273) 
Ainda durante a conversa, a menina contou que gostava dos livros de Zac Power e havia retirado aquele para que o pai lesse a ela, acrescentando que, quando ele não está trabalhando, "até que gosta de ler esses livros de criança". Consideramos, pois, que as experiências partilhadas de leitura, dentro da família, assumem uma dimensão fundamental na formação do gosto pela leitura, ou seja, o fato de os pais lerem para seus filhos pode funcionar como uma alavanca para uma posterior leitura mais autônoma. Assim, não é o contato com os objetos de leitura que garante a formação do leitor, mas as interações significativas que cercam esse contato.

Apesar de Laura classificar a coleção Zac Power como sendo infantil, notamos que há um considerável volume de texto, requisitando a mediação de um leitor mais experiente. Vale ressaltar que o livro foi selecionado na biblioteca por crianças de segundo ano, isto é, não havia restrição à retirada de livros pelas crianças, que, supostamente, tinham liberdade em suas escolhas literárias. Outro aspecto a ser mencionado é o fato de a coleção ter se popularizado entre as crianças da turma. Assim, é possível estabelecer relação com a ideia de sociabilidades em torno da leitura (CHARTIER, 2004) e também com a ideia de que não há correlação direta entre faixa etária e escolhas literárias, o que, muitas vezes, se coloca como uma "imposição" da escola e dos adultos para regular as leituras das crianças.

\section{A PERSPECTIVA DAS CRIANCCAS SOBRE OS GÊNEROS E OS SUPORTES DE LEITURA}

Este eixo, como o próprio título elucida, apresentará uma discussão sobre os gêneros e os suportes de leitura do ponto de vista dos participantes da pesquisa. Nosso interesse foi o de compreender de que modo as crianças identificavam esses materiais, nomeavam e os caracterizavam. Buscamos, assim, acessar informações que nos levassem a inferir os possíveis significados e funções atribuídos pelas crianças. Nesse momento, já nos defrontamos com uma situação complexa: identificar o gênero e o suporte desses materiais, por meio dos relatos descritivos orais que elas foram fazendo a respeito de cada um deles.

Isto nos leva a situar o conceito de gêneros discursivos. Os estudos sobre o conceito - tomando-se a perspectiva pioneira de Bakhtin (1992) sobre o tema - apontam para a impossibilidade de tratarmos de maneira rígida a caracterização e a funcionalidade dos gêneros. Sabe-se que são fenômenos históricos vinculados à cultura; estabilizam parcialmente as situações de comunicação do cotidiano; são extremamente diversificados, ajustando-se às práticas sociais e às suas mudanças. Por essas razões, é possível apontar, inicialmente, 
a complexidade de caracterizá-los e de classificá-los, indicando estruturas constantes em sua composição/utilização (DALLA ZEN, 2006). Marcuschi (2008, p. 17) destaca a dinamicidade, a historicidade e a plasticidade dos gêneros, mostrando que "[...] eles não são classificáveis como formas puras nem podem ser catalogados de maneira rígida" e segue enfatizando que devem ser vistos no interior da cultura e na relação com as práticas sociais e atividades discursivas. Ao colocar em suspeição os esforços para categorizar a noção de gêneros e suas classificações, argumenta: "O certo é que as dimensões geralmente adotadas para identificação e análise dos gêneros são sociocomunicativas e referem-se à função e organização, ao conteúdo e meio de circulação, aos atores sociais envolvidos e atividades discursivas implicadas [...]" (MARCUSCHI, 2008, p. 18). Dessa forma, fica assinalada, aqui, a necessidade de privilegiar o contexto de produção das escritas das crianças e suas famílias para acessar os gêneros e, igualmente, os suportes textuais em circulação.

Tendo em vista esse entendimento, foi possível compreender a busca pelas denominações verbalizadas pelas crianças ao se reportarem aos materiais por elas trazidos. A partir dessas falas compiladas no Quadro 2, construímos duas categorizações, quais sejam: gênero e suporte, sendo este convencional ou incidental. Foi considerado como "gênero" qualquer aspecto nomeado pela criança na relação com o referido conceito: nome, função, estilo ou forma composicional. Foi considerado "suporte", seja ele convencional ou incidental, quando a criança evocou a materialidade do objeto.

Seguem, então, exemplos de cada categorização (gênero ou suporte) a partir dos diálogos ${ }^{3}$ com os participantes do estudo. Iniciamos com os exemplos que evidenciam enunciados a respeito do nome e da função que caracterizam determinado gênero. Ainda que seja difícil classificar determinados dados quanto ao fato de serem gênero ou suporte, a partir do que disseram, optamos por fazê-lo por uma decisão analítica e, para tanto, consideramos o modo como são apresentados no Dicionário de Gêneros Textuais de Sérgio Roberto Costa (2009). 
Ka: eu conto as histórias pra minha irmã.

Da: Scooby-Doo os o monstro de da corrida de carros. ((apontando para o título do livro))

Fe: história sobre os pintinhos.

Fe: do Scooby-Doo.

Ka: esse aqui é do os piratas.

(Excertos 6 - Transcrição)

Observamos, acima, a recorrência do gênero história como primeira menção das crianças na apresentação dos materiais. Em seus relatos, elas apontam o nome ou o tema das histórias lidas já conhecidas. Pelos dados já discutidos nas seções anteriores, essa familiaridade com o gênero evidencia uma experiência de leitura construída na escola e na família.

Nos excertos a seguir, são privilegiados gêneros com a função comunicativa (bilhete, agenda e carta), pressupondo um interlocutor ausente (pais e irmã). Esses gêneros circulam tanto na esfera familiar quanto na escolar e, como se percebe, são reconhecidos pelas crianças no que diz respeito à sua função e importância, tal como se comprova nas palavras de Mateus.

Lu: aqui é o bilhete do passeio.

Me: é pra fazer oficina de reforço.

Ma: porque a agenda é muito importante.

Lu: uma carta.

Ta: a carta que a minha mãe manda pra minha irmã.

(Excertos 7 - Transcrição)

O calendário é o próximo gênero destacado pelas quatro crianças, cujos diálogos estão abaixo apresentados. Primeiramente, elas referem-se ao nome do gênero e, instigadas pela pesquisadora, abordam sua função em diferentes contextos (data, aniversário, orientações para plantios). Esta recorrência sinaliza o uso cotidiano deste material "de consulta" na esfera familiar e com frequência também na escolar. 
Ka: é calendário.

P: e quem é que usa?

Ka: ã, só olha pra ver o dia.

Ma: ca, len, da, ri, o.

P: e pra que que tu usa?

Ma: pra saber se eu não me lembro qual dia é.

Me: calendário.

P: e vocês usam pra fazer o quê, o calendário?

Me: que dia é, que dia é o seu aniversário.

Y: aí é o calendário que também tem coisas pra ler.

P: o que que tem pra ler?

Y: um monte de coisas, só como cuidar das plantas.

(Excertos 8 - Transcrição)

Prosseguindo, nota-se que três crianças fizeram referência ao mesmo objeto - imã de geladeira -, mencionando a função do mesmo com base em situações bem pragmáticas, tal como se observa nos excertos. Justamente por se referirem à função do gênero anúncio é que incluímos estes dados como exemplos do presente eixo - gênero.

Be: na geladeira, tem uma coisa que é escrito pra ligar pra coisa do poste, do bujão.

Gui: os números pra ligar pra encomendar pizza, pra bujão e pra ligar pra arrumar vídeo game.

$\mathrm{Ka}$ : pra comprar as coisas.

$\mathrm{Ka}$ : daí tu vê o número, daí tu liga.

P: e quem é que usa isso, quem é que liga na tua casa?

Ka: a minha mãe liga lá, pra trazer lá pão na casa.

P: e o que que vocês pedem de entrega assim em casa?

Ka: remédio, chá pra irmã.

(Excertos 9 - Transcrição) 
Neste próximo excerto, Laura não consegue nomear diretamente o gênero legenda, mas o faz explicando, de modo bem concreto, a função dos textos presentes nos filmes.

Lau: na televisão dá pra ver que que acontece, dá pra ler os filmes quando, quando assim inglês, assim fica.

(Excertos 10 - Transcrição)

Nos próximos dados aqui arrolados encontraremos designações, por parte das crianças, as quais relacionamos ao conceito de suporte. Faz-se oportuno, pois, retomar a noção de suporte, ou seja, o fato de que este é um lugar (físico ou virtual) com uma forma específica e com a finalidade de apresentar o texto (MARCUSCHI, 2003). Em se tratando da relação gênero e suporte, o autor diferencia suporte convencional e suporte incidental. Esclarece que o primeiro é produzido com o objetivo de portar ou fixar textos, enquanto o segundo, o incidental, porta textos ocasionalmente, isto é, não tem esta finalidade de forma regular.

O suporte que apresentou maior incidência entre as crianças foi o livro, assim nomeado na primeira evocação feita por elas. Novamente, aparecem em evidência as histórias infantis e livros religiosos, inclusive a Bíblia. Também foram incluídos, em uma única ocorrência, o livro didático e as inusitadas denominações "livro de responder as palavras" e "livro de futeboleiro", referentes à revista de palavras cruzadas e álbum de figurinhas de futebol. Sob o "guardachuva livro", então, Beatriz acopla suas designações criativas, valendose, secundariamente, da função do gênero para nomear o material de leitura/escrita, cujo nome específico ela desconhece, como se pode confirmar nos excertos abaixo.

Be: livro da Rapunzel.

Be: ela lê livro de Deus.

Lu: é o livro da escola.

Ma: livro, tem do Ben10 um monte.

Lau: trouxe o livro da bruxa e o livro do Zac Power.

Gui: agora aqui no livro do Zac Power, vários livros tem lá em casa. 
Ta: aqui é um livro, eu tenho livro na minha casa.

Ta: eu tenho um livro de Jesus, um livro de Barbie e um livro de fadinha.

Me: o livro que eu tenho em casa.

P: qual é?

Me: ele é bem, bem, bem velho.

Ka: é um livro também.

Ka: português.

P: onde que tu sabe, como é que tu sabe que é de português?

Ka: porque tá escrito português ((corre o dedo sob a palavra))

P: ah

Ka: alegria de saber ((faz a leitura acompanhando com os dedos))

Be: o livro de responder as palavras.

P: como é que é? Explica como é que ele funciona pra nós.

Be: ele, tu pega, aí tu tem ponto de interrogação, aí, aí tu responde a palavra. E tem uma assim, outra assim, outra assim ((imita a disposição em que as palavras ficam escritas no livro))

P: e tu chama de livro de?

Be: de palavras, de responder palavra.

Be: é o livro que tá escrito braseiro de sul, que é jogador.

$\mathrm{P}$ : o que que é mesmo isso aqui? Me explica melhor.

Be: isso aqui é livro de, de futebol.

P: esse é o livro?

Be: de futeboleiro.

Da: Bíblia.

K: é uma Bỉblia.

Ma: uma Bíblia do, do Jesus Cristo.

Me: uma Bíblia.

Vi: trouxe só Bíblia.

Y: aí é uma Bíblia da minha mãe.

(Excertos 11 - Transcrição) 
$\mathrm{Na}$ sequência dos suportes convencionais, apareceu o jornal. Interessante notar que as crianças indicam o nome do jornal acessado em casa, conferindo-lhes uma denominação associada ao título do periódico: Jornal O Sul e Diário Gaúcho. Também se percebe a circulação de um jornal comunitário, a exemplo do título Jornal de Paraíba, supostamente distribuído na comunidade em que a escola está inserida.

Gui: minha mãe e meu pai lê o jornal.

P: e qual é o jornal que vocês leem em casa?

Gui: jornal do sul.

Lu: jornal gaúcho.

Lau: jornal gaúcho.

Be: jornal de Paraíba.

(Excertos 12 - Transcrição)

Para o suporte revista, Yasmin relata uma prática de leitura compartilhada com sua irmã dentro de um contexto lúdico: "eu e a Vitória a gente brinca de revista". Esta representação da experiência de leitura permite a produção de textos orais, situações de comunicação ainda pouco pautadas nas ações pedagógicas frente à primazia da escrita.

Y: revista é isso.

Y: a minha mãe não lê, e eu e a Vitória a gente brinca de revista

P: e vocês brincam de ler revista? Como é que é essa brincadeira de revista?

Y: é assim ó, a gente pensa numa coisa escrita, daí a gente lê, faz de conta.

P: e inventa?

Y: aham

P: e inventa como?

Y: inventa que tá lendo.

(Excerto 13 - Transcrição)

Nos excertos que seguem, encontramos os suportes álbum, televisão e papel. O álbum, como se pode notar, aparece nomeado 
dentro da sua especificidade - de figurinhas -, enquanto a televisão e o papel são evocados para referência a gêneros que as crianças não denominam, quais sejam, legenda no primeiro caso e bula no segundo.

Y: é o meu álbum de figurinha do Carrossel.

Y: televisão, tem coisas pra ler.

P: que que tem pra lê na televisão?

Y: no Ratinho, ${ }^{4}$ tem umas coisas embaixo pra ler.

Me: um papelzinho que vem dentro da caixinha do remédio.

(Excertos 14 - Transcrição)

Passando aos suportes incidentais, notamos que, dentro da variedade apresentada, há uma recorrência das embalagens, o que sinaliza a circulação e o possível uso de produtos industrializados consumidos nas famílias dessas crianças, tal como ilustram os exemplos a seguir:

Be: uma caixa de leite, uma acetona, uma garrafa de refri, uma garrafa de água.

Gui: é o shampoo.

Y: eu trouxe uma caixa de gelatina.

Y: essa é uma garrafinha que eu ganhei da sora, todo mundo ganhou.

Lu: sabão, tem coisa escrita.

Fe: aqui é um potinho de margarina, tem uma caixinha de café, e tem shampoo, salgadinho de, de churrasco.

(Excertos 15 - Transcrição)

Diferentemente das crianças que apenas citaram o suporte, Tatiana, quando perguntada durante a interação com a pesquisadora, esclarece sobre o uso e o conteúdo das informações constantes nos rótulos, ou seja, evidenciando conhecimento sobre a funcionalidade da escrita, para identificação do produto antes de sua utilização. 
Ta: é shampoo e condicionador

P: e o que que tem pra lê ali?

Ta: é porque tem o negócio escrito, assim na frente ((aponta para o rótulo do shampoo desenhado))

P: e tu lê quando?

Ta: eu leio quando eu vou lavar os cabelos pra ver o que que é.

(Excertos 16 - Transcrição)

As roupas, sob nosso ponto de vista, são um exemplo bem concreto do caráter incidental como suporte e também, como já dissemos, são objetos de consumo presentes no cotidiano das crianças. Vale ressaltar a observação das marcas, aspecto que nos chamou a atenção como significados produzidos na cultura e bastante visibilizados pela mídia em geral.

Gui: o boné.

P: ah, o boné, e que que tem pra ler no boné?

Gui: só sei que a marca é N Y.

Ta: é uma camiseta, eu tenho uma camiseta com negócio escrito.

Ta: é por causa que tem uma meia também, que tem um negócio escrito.

(Excertos 17 - Transcrição)

Nessa mesma perspectiva, foram representados graficamente alguns objetos nos quais supostamente as crianças identificaram as marcas, o que possibilitou a referência ao fato de que nesses objetos haveria algo para ser lido.

K: é uma pilha.

Lau: ar condicionado.

Lau: aqui é a secadora de roupa, tem assim, tem pra ler assim um negócio que tem pra ler ali embaixo.

(Excertos 18 - Transcrição) 
Outro suporte acionado pelas crianças foram as cartas para colecionar e jogar, deslocadas de sua função original, qual seja, a de figuras autocolantes para álbuns colecionáveis. Esse deslocamento de função (da figura autocolante para o jogo) mostra essa prática de entretenimento disseminada, em larga escala, na turma em questão. Um dado curioso é o fato de que as cartas foram abordadas conosco como sendo um material de leitura; entretanto, para a ocasião do jogo, conforme o relato de Kauã, não é necessário ler para jogar.

Da: cartinha.

Ma: cartinha.

Vi: cartinhas.

Ka: é cartinha.

P: é cartinhas do quê?

Ka: do Pokémon. ((manuseia as cartas e organiza em grupos as de futebol e as de Pokémon))

Ka: Pokémon, futebol.

P: e tem coisa pra ler aî?

Ka: tem, aqui ó. ((mostra as escritas nas cartas))

P: e pra jogar tem que lê?

Ka: não.

(Excertos 19 - Transcrição)

O suporte fotografia foi citado por Yasmin e permite a constatação de que o mesmo funciona como evocador de memória, já que sua mãe registra os fatos e indica as datas dos acontecimentos para posterior retomada (recordação) e socialização com familiares. Mais uma vez, percebe-se a imbricada relação entre as práticas do ler e do escrever no contexto doméstico. 
Y: foto, muitas fotos.

P: como é que é isso? Como é que funciona, conta pra nós.

Y: a minha mãe sempre escreve, assim, se, se eu for me batizar, a minha escreve o ano, o dia, data.

P: então a mãe escreve isso e depois quem é que lê?

Y: a minha mãe de novo.

P: a mãe lê?

Y: daí ela manda algumas pro meu pai.

(Excerto 20 - Transcrição)

Em síntese, as crianças "catalogaram” os materiais trazidos e desenhados a partir de critérios muito concretos, isto é, referiramse, na maioria das vezes, ao suporte, reconhecendo-o e nomeando-o pela sua forma e conteúdo; enfim, o suporte indicava às crianças do que se tratava. Essa constatação qualitativa também se deu no nível quantitativo: verificado o montante de materiais apresentados e referenciados, evidenciou-se que dois terços do total foram considerados suporte e um terço, gênero. Assim sendo, identificouse que as crianças fizeram mais referência ao suporte, seja este convencional ou incidental, do que ao gênero.

Essa prevalência nos dados também possibilita aventar a hipótese de que a ausência de identificação dos gêneros pelas crianças pode estar associada à imprecisão lexical. Com um vocabulário ainda limitado em relação às características dos gêneros - a exemplo de "tem uma coisa que é escrito" (Beatriz), "tem umas coisas embaixo pra ler" (Yasmin), "tem um negócio escrito" (Tatiana), "negócio que tem pra ler" (Laura) - elas utilizaram denominações bastante amplas, distanciando-se das convencionais, como o "guarda-chuva livro", sob o qual foram abrigados distintos suportes e gêneros. Os resultados desta pesquisa apontam para que, mais do que possibilitar a ampliação do conhecimento de diferentes gêneros e suportes textuais, a escola precisa, com urgência, promover o desenvolvimento de comportamentos metatextuais que instiguem a capacidade de reflexão sobre a estrutura do texto, as características sociodiscursivas e estilísticas dos gêneros. Nesse sentido, Soares (2016, p. 139) explica consciência metatextual como a "capacidade de crianças de discriminar ou identificar diferentes gêneros de textos, explicitar 
critérios usados para essa discriminação e identificação, refletir sobre a estrutura do texto". Os professores, portanto, precisam planejar e desenvolver, com regularidade e intensidade, sequências didáticas que promovam habilidades para identificar, compreender e produzir gêneros textuais com autonomia.

\section{PARA CONCLUIR: ALGUMAS IMPLICAC̣ÕES PEDAGÓGICAS}

Optamos, neste espaço, como já anunciado no início deste texto, por delinear algumas implicações pedagógicas decorrentes da discussão dos dados, considerando que tal caminho permitirá ao leitor articulações possíveis entre as práticas de leituras identificadas fora do ambiente escolar e que foram analisadas e o planejamento de práticas escolares a partir dos dados obtidos. Segue, então, um breve inventário de ideias quanto à necessidade de a escola:

1) abrir-se à variedade de materiais e de práticas de leitura em circulação no contexto sociocultural das crianças, indo além, por exemplo, do trabalho pedagógico tão usual com rótulos e embalagens. As crianças desta pesquisa nos mostraram que se interessam muito pelo que está escrito em suas roupas, nos acessórios que usam e que em suas mochilas há outros materiais de leitura, para além dos escolares, sobre os quais têm muito a dizer e a compartilhar.

2) adotar um olhar sensível e arguto frente aos "recados" que as crianças endereçam quanto ao uso e função dos materiais que carregam consigo, por exemplo: elaborar um jogo em que, para jogá-lo, seja necessário ler as informações constantes nas cartinhas, sendo a leitura requisito para participação efetiva em práticas lúdicas, que tanto atraem as crianças.

3) investir em materiais para além do caderno com pautas, suporte de escrita convencional escolar. Escrever e ler em folhas em diferentes tamanhos e formatos (circulares, triangulares...), sem pautas, provoca que a criança lance mão de novas estratégias para planejar, organizar e ler sua escrita sem a limitação imposta pelas linhas. A utilização de marcatextos, canetas coloridas e, por que não, post-its poderia ser institucionalizada na escola como recursos que motivem comportamentos leitores de estudo e revisão de textos.

4) possibilitar que a biblioteca na escola (tanto a da sala de aula quanto a da instituição) funcione como um polo potencializador 
de formação de leitores literários. Os livros de contos que as crianças participantes tinham em casa eram, em sua maioria, os emprestados pela biblioteca da escola e, no contexto doméstico, funcionavam como disparadores de práticas de leitura compartilhadas entre familiares. Assim, a vivência de um espaço social de leitura literária na escola também pode (e deve!) se dar pela socialização das escolhas entre as próprias crianças em rodas de leitura e comunidades de leitores.

5) eleger textos de circulação social e literários, apresentando-os junto aos seus suportes originais no momento do planejamento e desenvolvimento de práticas de leitura. Retornar ao mesmo texto diversas vezes, provocando o uso de diferentes estratégias de leitura com vistas ao desenvolvimento da fluência. Nesses textos, selecionar palavras de alta frequência na língua para que sejam exaustivamente lidas, analisadas, escritas para que, assim, possam ir compondo o léxico ortográfico e semântico da turma, o que, como já argumentado, promove o uso da rota lexical com vistas aos automatismos da leitura proficiente.

6) valorizar as práticas de leitura das crianças e tomá-las como ponto de partida para o ensino, mas ir além delas, ampliandoas para habilidades mais complexas e associadas: não basta, por exemplo, decifrar um texto se a compreensão não é acessada, como no caso de Vinícius. Há diferenças significativas entre práticas leitoras e compreensão leitora, sendo essa última compromisso primordial de ensino da escola, o que exige tratamento didático específico e mediação docente qualificada entre leitor e texto.

7) promover a imersão das crianças no estudo dos gêneros e suas características estruturais e sociodiscursivas, dimensões da consciência metatextual nem sempre abordadas na exploração dos textos de leitura, por meio de sequências didáticas que possibilitem a leitura, a análise e a produção dos gêneros selecionados, desde o primeiro ano do Ensino Fundamental. Partir de gêneros com os quais as crianças têm mais familiaridade para que as habilidades de leitura a eles associadas e o conhecimento de suas características sejam gradativamente aprofundados ao longo dos anos iniciais em relação a novos gêneros, com maior nível de formalidade e complexidade.

8) engajar-se, com o coletivo de professores nas redes, na definição de quais habilidades e gêneros são necessários para o 
uso efetivo da leitura e da escrita nas sociedades contemporâneas e que, portanto, precisam ser ensinados na escola. Morais (2018) defende a definição clara e detalhada de metas em relação ao que deve ser priorizado na alfabetização, prática que tem sido desenvolvida por Soares no trabalho que coordena no município de Lagoa Santa/MG e é por ele analisado nesse estudo referenciado, tendo em vista o propósito explícito de assegurar as aprendizagens a todos os alunos.

Enfim, ciente das limitações que a natureza deste trabalho impõe, por se tratar de um contexto específico, obviamente, não almejamos generalizações, mas a quantidade significativa de dados de pesquisa aqui arrolada nos leva a defender a importância do papel da escola na consideração das experiências de leitura vividas pelas crianças fora do ambiente escolar. Esta pesquisa demonstrou que: as crianças de camadas populares têm acesso à variedade de materiais de leitura e os reconhecem em seus suportes, assim como, em vários contextos, assumem uma posição de protagonistas das práticas de leitura. Entendemos, porém, que isso não é suficiente: é urgente, pois, investir no trabalho com os gêneros a partir de sequências didáticas, adequadamente planejadas, que possibilitem a apropriação, desde o início da alfabetização, das características estruturais e sociodiscursivas já mencionadas. Esperamos ter conseguido, neste texto, demonstrar a potencialidade e a necessidade de um olhar mais amplo e multifacetado para a compreensão das práticas de leitura das crianças, especialmente quando nos voltamos a tecer relações com as práticas escolares. Se nossa premissa foi visibilizar os conhecimentos das crianças acerca da leitura, foi justamente para, a partir disso, promover a ampliação e a complexificação desse repertório na escola tendo em vista a formação de leitores proficientes.

\section{REFERÊNCIAS}

BAKHTIN, M. Estética da criação verbal. São Paulo: Martins Fontes, 1992.

CHARTIER, R. Do livro à leitura. As práticas urbanas do impresso. (1660-1790). In: CHARTIER, R. Leituras e leitores da França do Antigo Regime. São Paulo: UNESP, 2004. P. 173-234.

CHARTIER, R. A aventura do livro: do leitor ao navegador. São Paulo: UNESP, 2009.

CHARTIER, R. Do livro à leitura. In: CHARTIER, R. (org.). Práticas de leitura. São Paulo: Estação Liberdade, 2000. P. 77-105. 
COSTA, S. R. Dicionário de gêneros textuais. Belo Horizonte: Autêntica, 2009.

DALLA ZEN, M. I. H. "Foi num dia ensolarado que tudo aconteceu": práticas culturais em narrativas escolares. Porto Alegre: UFRGS, 2006. 209 f. Tese (Doutorado em Educação).

EHRI, L. Aquisição da habilidade de leitura de palavras e sua influência na pronúncia e na aprendizagem do vocabulário. In: MALUF, M. R.; CARDOSO-MARTINS, C. (org.). Alfabetização no século XXI: como se aprende a ler e a escrever. Porto Alegre: Penso, 2013. P. 49-81.

FERREIRO, E. Acerca de rupturas ou continuidades na leitura e escrita. In: FERREIRA, E. (org.). O ingresso na escrita e nas culturas do escrito: seleção de textos de pesquisa. São Paulo: Cortez, 2013. P. 423-443.

FERrEiro, E.; TEBEROSKY, A. Psicogênese da língua escrita. Porto Alegre: Artes Médicas, 1986.

GATTI, B. Grupo focal na pesquisa em Ciências Sociais e Humanas. Brasília - DF: Liber Livro, 2005.

GRAUE, M. E.; WALSH, D. J. Investigação etnográfica com crianças: teorias, métodos e ética. Lisboa: Fundação Calouste Gulbenkian, 2003.

MARCUSCHI, L. A.. A questão do suporte dos gêneros textuais. DLCV: Língua, Linguística e Literatura, João Pessoa, v. 1, n. 1, p. 9-40, 2003.

MARCUSCHI, L. A. Gêneros textuais: configuração, dinamicidade e circulação. In: KARWOSKI, A. M.; GAYDECZKA, B.; BRITO, S. K. (org.). Gêneros textuais: reflexões e ensino. Rio de Janeiro: Nova Fronteira, 2008, P. 15-28.

MIRANDA, A. R. M. Aquisição da escrita: as pesquisas do GEALE. In: MIRANDA, A. R. M.; CUNHA, A. P. N. da; DONICHT, G. (org.). Estudos sobre aquisição da linguagem escrita. Pelotas: Ed. UFPel, 2017. P. 15-50.

MIRANDA, A. R. M.; MATZENAUER, C. L. B. Aquisição da fala e da escrita: relações com a fonologia. Cadernos de Educação, FAE/PPGE/UFPel. Pelotas, n. 35, p. 359-405, jan./ abr. 2010. Disponível em: https://periodicos.ufpel.edu.br/ojs2/index.php/caduc/article/ view/1626/1509. Acesso em: set. 2018.

MORAIS, A. G. de. A republicana proposta curricular de Língua Portuguesa que Magda Soares vem construindo com os educadores de Lagoa Santa - MG: coerência e inovação. Práxis Educativa: Ponta Grossa, v. 13, n. 3, p. 857-877, set./dez. 2018. Disponível em: http:// www.revistas2.uepg.br/index.php/praxiseducativa/article/view/12255/209209210249. Acesso em: jul. 2018.

MORAIS, A. G. de. Sistema de escrita alfabética. São Paulo: Melhoramentos, 2012.

MORAIS, J. ; LEITE, I.; KOLINSKY, R. Entre a pré-leitura e a leitura hábil: condições e patamares da aprendizagem. In: MALUF, M. R.; CARDOSO-MARTINS, C. (org.). Alfabetização no século XXI: como se aprende a ler e a escrever. Porto Alegre: Penso, 2013. P. 17-48. 
PICCOLI, L. Alfabetizações, alfabetismos e letramentos: trajetórias e conceitualizações. Educação \& Realidade, v. 35, n. 3, p. 257-275, set./dez. 2010.

RIBEIRO, V. M. Por mais e melhores leitores: uma introdução. In: RIBEIRO, Vera. Masagão. (org.). Letramento no Brasil. São Paulo: Global, 2004. P. 9-29.

ROCHA, E. A. C. Por que ouvir crianças? Algumas questões para um debate científico multidisciplinar. In: CRUZ, S. H. V. (org.). A criança fala: a escuta de crianças em pesquisa. São Paulo: Cortez, 2008. P. 43-51.

SOARES, M. Alfabetização: a questão dos métodos. São Paulo: Contexto, 2016.

SOARES, M. Práticas de letramento e implicações para a pesquisa e para políticas de alfabetização e letramento. In: MARINHO, M.; CARVALHO, G. T. (org.). Cultura escrita e letramento. Belo Horizonte: Editora UFMG, 2010. P. 54-67.

SOLÉ, I. O ensino da leitura. In: SOLÉ, I. Estratégias de leitura. Porto Alegre: Artmed, 2009. P. 49-65.

SPINILLO, A. G. Alfabetização e consciência metalinguística: da leitura da palavra à leitura do texto. In: MALUF, M. R.; CARDOSO-MARTINS, C. (org.). Alfabetização no século XXI: como se aprende a ler e a escrever. Porto Alegre: Penso, 2013. P. 138-154.

STREET, B. Os novos estudos sobre o letramento: histórico e perspectivas. In: MARINHO, M.; CARVALHO, G. T. (org.). Cultura escrita e letramento. Belo Horizonte: Editora UFMG, 2010. P. 33-53.

STREET, B.; LEFSTEIN, A. Literacy: an advanced resource book. $1^{\text {a }}$ ed., London / New York: Routledge, 2007.

\section{NOTAS}

1 Projeto registrado sob o número 18419 no Sistema de Pesquisa da UFRGS, com apoio do PIBIC/CNPq/UFRGS. A pesquisa contou com a autorização do Comitê de Ética em Pesquisa da UFRGS, tendo suas abordagens e instrumentos metodológicos em consonância aos procedimentos éticos estabelecidos para pesquisa que envolve seres humanos.

2 As transcrições foram realizadas de forma ortográfica, levando-se em conta as seguintes convenções: uso de sinais de pontuação; uso de sublinhado para indicar segmentos lidos; uso de duplo parênteses para indicar comentários; uso de segundos entre parênteses para indicar pausas relevantes. Nos diálogos entre pesquisadora e criança, foram usadas as letras P para a primeira e a sílaba inicial do nome fictício para a segunda. Os excertos do diário de campo e de transcrição selecionados são apresentados, aqui, em caixas de texto.

3 Muitos excertos deste eixo são advindos de diferentes encontros e grupos, não se configurando em situações interativas do grupo focal.

4 Programa exibido pelo Sistema Brasileiro de Televisão (SBT). 
Submetido: $27 / 02 / 2019$

Aprovado: 01/11/2019

Contato:

Luciana Piccoli

Faculdade de Educação da Universidade Federal do Rio Grande do Sul

Av. Paulo Gama, s/n, Prédio 12201

Porto Alegre |RS|Brasil

CEP 90.046-900 